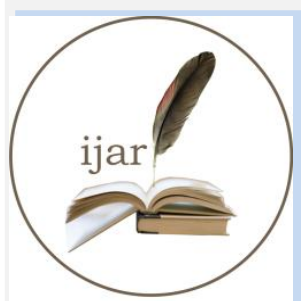

ISSN NO. 2320-5407
Journal Homepage: $-\underline{w w}$.journalijar.com
INTERNATIONAL JOURNAL OF
ADVANCED RESEARCH (IJAR)

Article DOI: 10.21474/IJAR01/1318

DOI URL: http://dx.doi.org/10.21474/IJAR01/1318
INTERNATIONAL JOURNAL OF ADVANCED RESEARCH (JJAR)

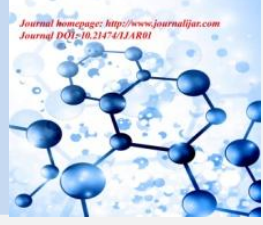

RESEARCH ARTICLE

\title{
NATURAL RADIOACTIVITY DUE TO RADON IN DWELLINGS OF KARBALA CITY, IRAQ
}

\author{
Abdalsattar Kareem Hashim and Elham Jasim Mohammed. \\ Department of Physics, College of Science, Kerbala University,Karbala, Iraq.
}

\section{Manuscript Info}

Manuscript History

Received: 18 June 2016

Final Accepted: 19 July 2016

Published: August 2016

Key words:-

Radon ,Equilibrium factor ,Annual effective dose, CR-39, Karbala.

\section{Abstract}

In the present work a set of indoor radon levels were measured carried out in different dwellings in Karbala city of Karbala governorate in middle of Iraq. Radon concentrations were determined by using time-integrated passive radon dosimeters( closed and open)containing (CR-39) solid state nuclear track detectors. Measurements were carried out during the three months (November and December of 2015 and Januaryof 2016).

The results show that, the radon concentrations varied from(32.21$139.01) \mathrm{Bq} / \mathrm{m}^{3}$ with an average value $(62.07) \mathrm{Bq} / \mathrm{m}^{3}$, and $(36.70$ $243.97) \mathrm{Bq} / \mathrm{m}^{3}$ with an average value $(93.36) \mathrm{Bq} / \mathrm{m}^{3}$ for closed and open dosimeters respectively, which are less than the lower limit of recommended range $\left(200-300 \mathrm{~Bq} / \mathrm{m}^{3}\right)$ (ICRP, 2009). . The values of the indoor annual effective dose vary from $(0.02-2.76) \mathrm{mSv} / \mathrm{y}$ with an average value $(0.68) \mathrm{mSv} / \mathrm{y}$ and $(0.02-7.49) \mathrm{mSv} / \mathrm{y}$ with an average value (1.43) $\mathrm{mSv} / \mathrm{y}$ for closed and open dosimeters respectively, which are less than the lower limit of the recommended range $(3-10 \mathrm{mSv} / \mathrm{y})$ (ICRP, 1993). The values of equilibrium factor vary from(0.008-0.94) with an average value $(0.18)$ Which is less than the value adopted by the(UNSCEAR, 2000).

Copy Right, IJAR, 2016,. All rights reserved.

\section{Introduction:-}

Radon as a natural noble gas, has three main natural isotopes; namely, radon-222 $\left({ }^{222} \mathrm{Rn}\right)$, a decay product of ${ }^{238} \mathrm{U}$,radon-220 $\left({ }^{220} \mathrm{Rn}\right.$, known as thoron), produced in the decay series of thorium-232 $\left({ }^{232} \mathrm{Th}\right)$, and radon-219 $\left({ }^{219} \mathrm{Rn}\right.$, known as actinon), a decay product from the chain originating with ${ }^{235} \mathrm{U}[1]$. Both ${ }^{238} \mathrm{U}$ and ${ }^{232} \mathrm{Th}$ occur naturally in soil and rocks at variable concentrations of about $1 \mathrm{pCi} / \mathrm{g}$ and also ${ }^{226} \mathrm{Ra}$ the parent of ${ }^{222} \mathrm{Rn}$ [2]. The half-life of ${ }^{222} \mathrm{Rn}$ isotope is 3.82 days; whil ${ }^{220} \mathrm{Rn}$ isotope has a half-life of 55 seconds and ${ }^{219} \mathrm{Rn}$ isotope has a half-life of about 3.96 seconds. ${ }^{222} \mathrm{Rn}$ decays intopolonium-218 $\left({ }^{218} \mathrm{Po}\right)$, which in turn decays within minutes to lead-214 $\left({ }^{214} \mathrm{~Pb}\right)$, bismuth$214\left({ }^{214} \mathrm{Bi}\right)$, and polonium-214 $\left({ }^{214} \mathrm{Po}\right)$ [3].The radon gas can diffuse easily out of the soil surface into air or houses; it can be trapped in poorly ventilated houses, and so its concentration can build up to higher levels. Although soil is considered to be the main source of indoor radon concentration, raw building materials (especially quartz, cement, etc.) can make a significant contribution to the level of natural radioactivity in closed spaces such as: stores and badly-ventilated dwellings [4].Moreover, the production rate of radon in dwellings depends on the concentration of radium content in the subsoil, building materials, and porosity, as well as the density of the wall material $[5,6]$. The emission of radon from building materials is found to be a function of ventilation, as well as of the radium content in building materials. The nongaseous ${ }^{222} \mathrm{Rn}$ decay products are partially suspended in air, as a mixture of attached and unattached fractions and partially deposited on walls and furniture [7]. 
The aims of the present study are to determine indoor radon level in the dwellings in Karbala city and to calculate the annual effective dose (AED) due to radon and its isotopes after determining equilibrium factor in every house was included in the study.

\section{Geological setting:-}

Karbala is the center of the governorate of Karbala, which is located in the middle of Iraq as a part of the alluvial plain, the river Al-Husseineya, a branch of the Euphrates (29) km, runs across its land. Geographically, it's bordered by the capital Baghdad at (105) km from the city center to the North, Al-Anbar governorate at (112)km to the North and the Western North, Al-Najaf governorate at $(74) \mathrm{km}$ to the South and the Western South, and Babylon governorate at (45) $\mathrm{km}$ to the South and the Eastern South. Karbala city occupies the Northern East part of Karbala governorate. In the North it is neighbored by Al-Hur district, the South by desert, at the East Al-Husseineya district and Al-Hindeya, while the desert and Al-Razzazah lake borders the West indicated in Fig. 1, with location of latitude $\left(32^{\prime}, 34^{\circ}-32^{`} .37^{\circ} \mathrm{N}\right)$, and longitude $\left(58^{\circ}, 43^{\circ}-60^{`}, 44^{\circ} \mathrm{E}\right)$. Karbala city resides on (2793) $\mathrm{km}^{2}$ [8].

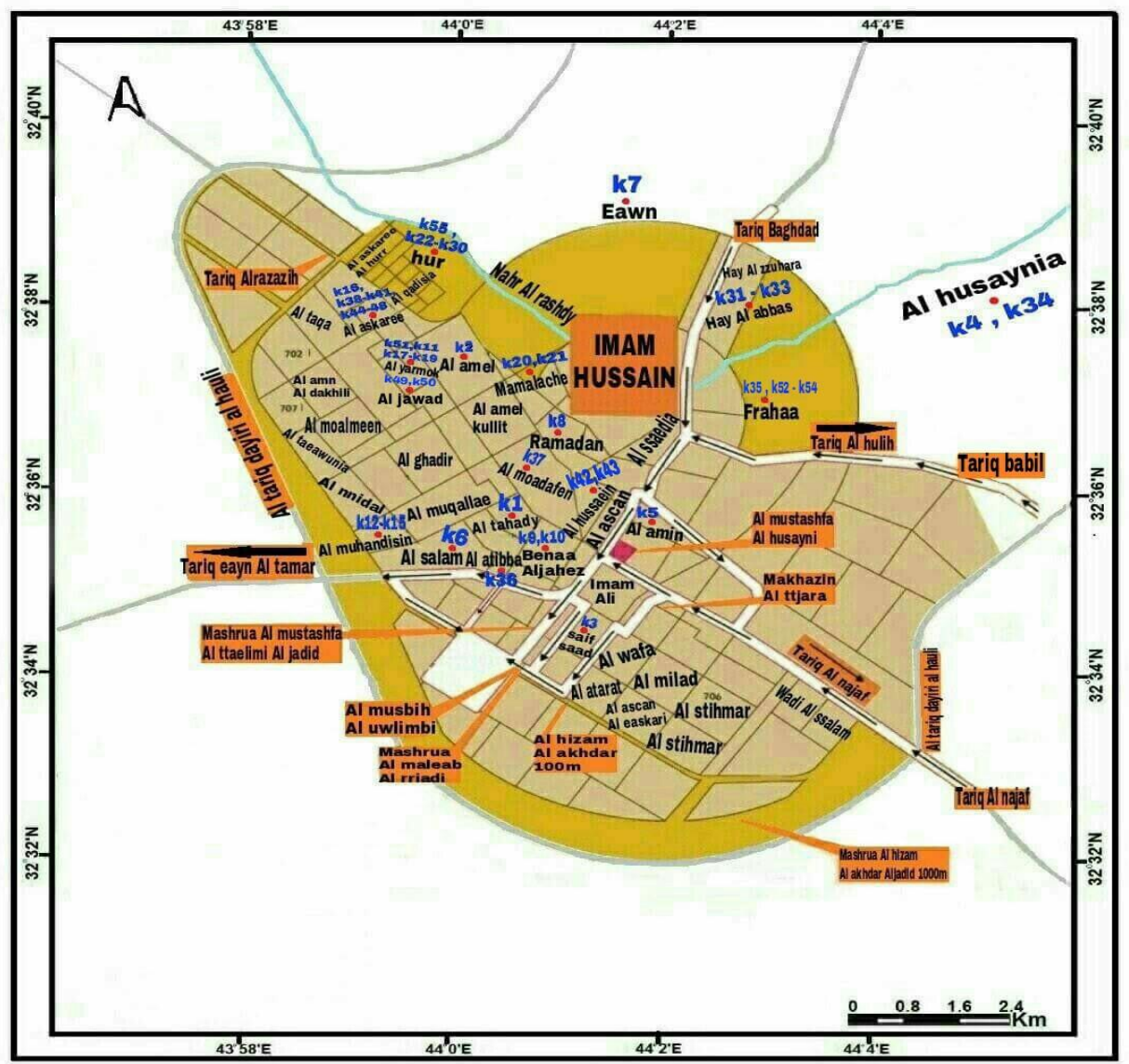

Figure 1:- Sketch map shows locations of study samples in Karbala city.

\section{Measuring procedures:-}

Radon activity concentrations indoor were measured in Karbala city (middle of Iraq) using passive closed- and open-can techniques employing high-quality CR-39 from PershoreMoulding Ltd; UK. The system consists of a cylindrical plastic cup (see in figure 2) having a $1.3 \mathrm{~cm}$ hole covered with $0.5 \mathrm{~cm}$ thick compressed sponge to filter out dust and thoron. Pieces $\left(1.5 \times 1.5 \mathrm{~cm}^{2}\right)$ of CR-39 detector were fixed in the bottom of the cup using double face adhesive tape. About 55 houses were selected randomly from the study area. Two monitors (one with filter and one without) were placed in each house, specifically, in the most frequently used room at a distance of at least $0.5 \mathrm{~m}$ from the walls, ceilings and floors. After three months( 90 days $)$ of exposure these detectors were chemically etched using $6.25 \mathrm{M}(\mathrm{NaOH})$ solution at $70^{\circ} \mathrm{C}$ for 8 hours. After etching, the detectors were washed with distilled water. After drying, the tracks were counted using an optical microscope having a magnification of $100 \mathrm{X}$ 


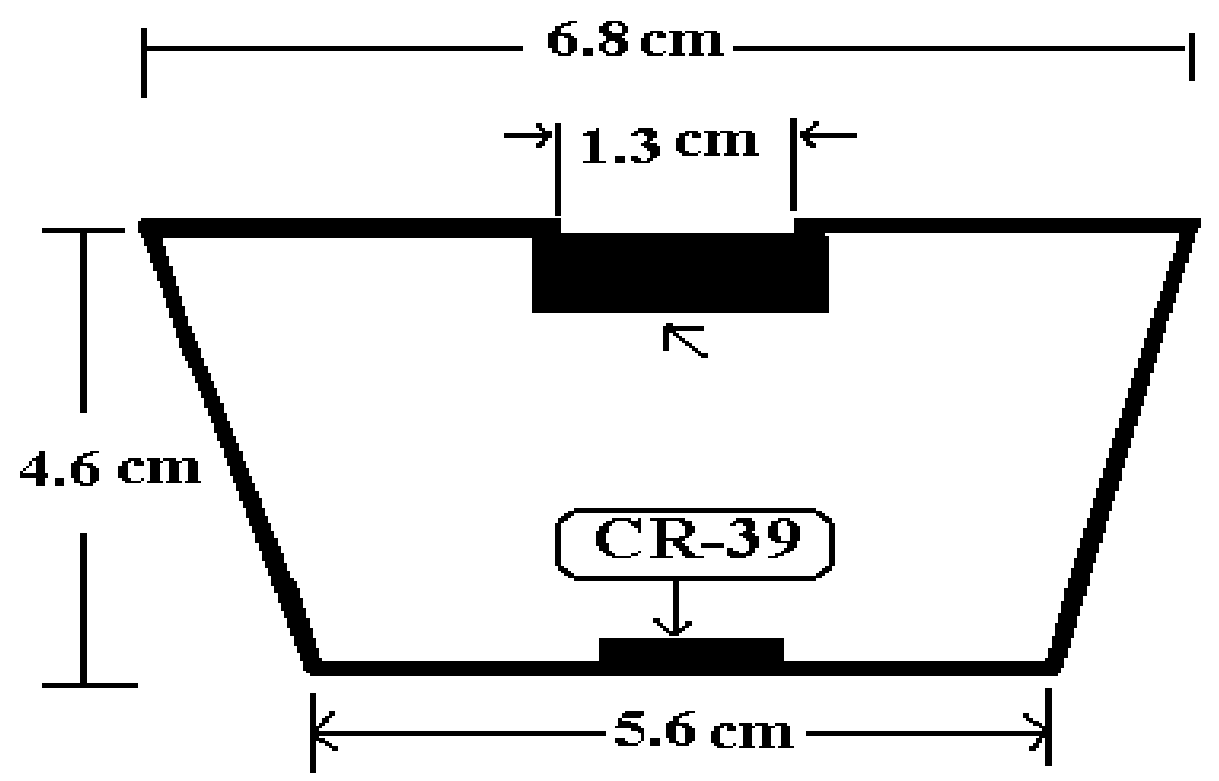

Figure 2:-Dosimeter radon passive cumulative.

The average radon concentration $(\mathrm{C})$ was measured by passive methods, calculated as $[9,10]$ :

$$
\mathrm{C}\left(\mathrm{Bq} \cdot \mathrm{m}^{3}\right)=\rho / \mathrm{k} . \mathrm{t}
$$

Where $(\rho)$ is the track density (track $\left./ \mathrm{cm}^{2}\right),(\mathrm{k})$ is the calibration factor which was found experimentally to be equal to $\left(0.223\right.$ track. $\left.\mathrm{cm}^{-2} / \mathrm{Bq} . \mathrm{d} . \mathrm{m}^{-3}\right)$, and $(\mathrm{t})$ is the exposure time which is equal to (90) days.

After concentrations of radon account closed and open dosimeters in all dwelling, we were able to calculate the equilibrium factor $(\mathrm{F})$ in all the dwelling of the study, using the following relationship[11, 12]: -

$$
F=a \exp \left(-b \frac{C c}{C o}\right)
$$

The annual effective dose (AED) in terms of (mSv/y) units was obtained using the relation [13-15]:

$\operatorname{AED}(\mathrm{m} \mathrm{Sv} / \mathrm{y})=\mathrm{C} \times \mathrm{F} \times \mathrm{H} \times \mathrm{T} \times \mathrm{D}$

Where $\mathrm{F}$ is the equilibrium factor, $(\mathrm{H})$ is the occupancy factor which is equal to $(0.8),(\mathrm{T})$ is the time in hours in a year $(\mathrm{T}=8760 \mathrm{~h} / \mathrm{y})$, and $(\mathrm{D})$ is the dose conversion factor which is equal to $\left[9 \times 10^{-6}(\mathrm{~m} \mathrm{~Sv}) /(\mathrm{Bq} \cdot \mathrm{h} \cdot \mathrm{m}-3)\right]$

\section{Results and Discussion:-}

In the present work indoor radon concentrations, were measured for 55 dwellings in Karbala city as in table (1).Table (2) summarize the results obtained in the present work for radon gas concentrations in indoor dwellings in different sites in Karbala city, For closed dosimeters, it can be noticed that, the highest average radon concentration in indoor dwellings was found in $\mathrm{K} 4$ dwelling which was $\left(139.01 \mathrm{~Bq} / \mathrm{m}^{3}\right.$ ), while the lowest average radon concentration was found in $\mathrm{K} 14$ dwelling which was $\left(32.21 \mathrm{~Bq} / \mathrm{m}^{3}\right)$, see Figure (3), with an average value of $\left(62.07 \mathrm{~Bq} / \mathrm{m}^{3}\right)$. In addition that, for open dosimeters, Table(2) it can be noticed that, the highest average radon concentration in indoor dwellings was found in $\mathrm{K} 4$ dwelling which was $\left(243.97 \mathrm{~Bq} / \mathrm{m}^{3}\right)$, while the lowest average radon concentration was found in $\mathrm{K} 48$ dwelling which was $\left(36.70 \mathrm{~Bq} / \mathrm{m}^{3}\right)$, see Figure (3), with an average value of $\left(93.36 \mathrm{~Bq} / \mathrm{m}^{3}\right)$ In all the dwellings surveyed in the present work, radon concentrations is less than even the lower limit of the recommended range (200- $300 \mathrm{~Bq} / \mathrm{m} 3$ ) (ICRP, 2009) [16]. Also from Table 2 and Figure 4, for closed dosimeters, it can be noticed that the annual effective dose (AED) received by the residents of the study area varies from $(0.02 \mathrm{mSv} / \mathrm{y}))(\mathrm{K} 6 \mathrm{dwelling})$ to $(2.76 \mathrm{mSv} / \mathrm{y})(\mathrm{K} 11 \mathrm{dwelling})$ with an average value of $(0.68 \mathrm{mSv} / \mathrm{y})$. While in open dosimeter, it can be noticed that, the annual effective dose (AED) received by the residents of the study area varies from $(0.02 \mathrm{mSv} / \mathrm{y})(\mathrm{K} 6 \mathrm{dwelling})$ to $(7.49 \mathrm{mSv} / \mathrm{y})(\mathrm{K} 11 \mathrm{dwelling})$ with an average value of $(1.43 \mathrm{mSv} / \mathrm{y}) . \mathrm{In}$ all the dwellings surveyed in the present work, the indoor annual effective dose is less than even the lower limit of the recommended range (3-10 mSv/y) (ICRP, 1993) [17]. From Table 2 and Figure 5, The equilibrium factor values varies from (0.008) (K6 dwelling) to (0.94) (K11 dwelling), with an average value of (0.18), The equilibrium factor is less than even the lower limit of the recommended $(0.4-1)$ [18]. 
Considering the great importance of radon as a result of the health effects on human life, many researchers have made in various countries around the world to conduct research and studies to measure the concentrations effective dose of it in the air of homes of those countries in order to reduce the risks resulting from it and develop the necessary solutions to it through special programs. The table (3) shows the results of some studies and research in various countries around the world and to compare the results of this study.

Table 1:- Symbol, and location name of the different studied sites in Karbala city of Karbala governorate.

\begin{tabular}{|c|c|c|c|c|c|c|c|}
\hline $\begin{array}{c}\text { Sample } \\
\text { Code }\end{array}$ & Location & $\begin{array}{c}\text { Sample } \\
\text { Cod. }\end{array}$ & Location & $\begin{array}{c}\text { Sample } \\
\text { Cod. }\end{array}$ & Location & $\begin{array}{c}\text { Sample } \\
\text { Cod. }\end{array}$ & Location \\
\hline K1 & Tahady & K15 & $\begin{array}{c}\text { Al } \\
\text { muhandisin }\end{array}$ & K29 & Al hur & K43 & Al hussein \\
\hline K2 & Amel & K16 & Askaree & K30 & Al hur & K44 & Askaree \\
\hline K3 & SaifSaad & K17 & Yarmouk & K31 & $\mathrm{Al}$ abbas & K45 & Askaree \\
\hline K4 & Hosainia & K18 & Yarmouk & K32 & Al abbas & K46 & Askaree \\
\hline K5 & Alamin & K19 & Yarmouk & K33 & Al abbas & K47 & Askaree \\
\hline K6 & Salam & K20 & Mamalachy & K34 & Hosainia & K48 & Askaree \\
\hline K7 & Eawn & K21 & Mamalachy & K35 & Frehaa & K49 & Al jawad \\
\hline K8 & Ramadan & K22 & Al hur & K36 & Al atibba & K50 & Al jawad \\
\hline K9 & Benaa al jahez & K23 & Al hur & K37 & Al moadafeen & K51 & Yarmouk \\
\hline K10 & Benaa al jahez & K24 & Al hur & K38 & Askaree & K52 & Frehaa \\
\hline K11 & Yarmouk & K25 & Al hur & K39 & Askaree & K53 & Frehaa \\
\hline K12 & Al muhandisin & K26 & Al hur & K40 & Askaree & K54 & Frehaa \\
\hline K13 & Al muhandisin & K27 & Al hur & K41 & Askaree & K55 & Al hur \\
\hline K14 & Al muhandisin & K28 & Al hur & K42 & Al hussein & & \\
\hline
\end{tabular}

Table 2:- Radon gas concentration (C ), equilibrium factor(F) and annual effective dose (AED ) for passive closed $(\mathrm{C})$ and open $(\mathrm{O})$ dosimeters in dwellings in Karbala city.

\begin{tabular}{|c|c|c|c|c|c|c|c|c|c|c|c|}
\hline Code & $\begin{array}{c}\mathbf{C c} \\
\left(\mathbf{B q} / \mathbf{m}^{3}\right)\end{array}$ & $\begin{array}{c}\text { Co } \\
\left(\mathbf{B q} / \mathbf{m}^{3}\right)\end{array}$ & $\mathbf{F}$ & $\begin{array}{l}\text { AED(c) } \\
(\mathrm{mSv} / \mathrm{y})\end{array}$ & $\begin{array}{l}\operatorname{AED}(\mathbf{o}) \\
(\mathrm{mSv} / \mathrm{y})\end{array}$ & Code & $\begin{array}{c}\mathbf{C c} \\
\left(\mathbf{B q} / \mathbf{m}^{3}\right)\end{array}$ & $\begin{array}{c}\mathrm{Co} \\
\left(\mathbf{B q} / \mathbf{m}^{3}\right)\end{array}$ & $\mathbf{F}$ & $\begin{array}{l}\text { AED(C) } \\
(\mathrm{mSv} / \mathrm{y})\end{array}$ & $\begin{array}{c}\text { AED(O) } \\
(\mathrm{mSv} / \mathrm{y})\end{array}$ \\
\hline K1 & 114.26 & 170.23 & 0.09 & 0.70 & 1.04 & K30 & 39.69 & 43.17 & 0.01 & 0.03 & 0.04 \\
\hline K2 & 78.55 & 80.88 & 0.01 & 0.05 & 0.05 & K31 & 50.98 & 54.80 & 0.01 & 0.04 & 0.04 \\
\hline K3 & 39.69 & 87.19 & 0.49 & 1.23 & 2.71 & K32 & 48.16 & 51.15 & 0.01 & 0.03 & 0.04 \\
\hline K4 & $\begin{array}{l}139.01 \\
\end{array}$ & 243.97 & 0.20 & 1.83 & 3.21 & K33 & 39.36 & 41.35 & 0.01 & 0.02 & 0.03 \\
\hline K5 & 48.82 & 49.82 & 0.009 & 0.02 & 0.03 & K34 & 62.44 & 103.30 & 0.16 & 0.63 & 1.04 \\
\hline K6 & 49.99 & 50.15 & 0.008 & 0.02 & 0.02 & K35 & 61.94 & 126.05 & 0.37 & 1.46 & 2.99 \\
\hline K7 & 86.86 & 92.00 & 0.01 & 0.06 & 0.11 & K36 & 62.11 & 98.98 & 0.13 & 0.53 & 0.84 \\
\hline K8 & 85.53 & 96.66 & 0.01 & 0.10 & 0.11 & K37 & 45.83 & 50.82 & 0.01 & 0.05 & 0.05 \\
\hline K9 & 70.25 & 142.99 & 0.37 & 1.66 & 3.39 & K38 & 40.35 & 76.23 & 0.28 & 0.72 & 1.36 \\
\hline K10 & 58.79 & 96.66 & 0.15 & 0.58 & 0.95 & K39 & 39.36 & 41.35 & 0.01 & 0.02 & 0.03 \\
\hline K11 & 46.16 & 125.39 & 0.94 & 2.76 & 7.49 & K40 & 32.88 & 45.83 & 0.06 & 0.14 & 0.19 \\
\hline K12 & 64.60 & 89.68 & 0.06 & 0.27 & 0.38 & K41 & 56.13 & 61.11 & 0.01 & 0.05 & 0.05 \\
\hline K13 & 43.34 & 108.12 & 0.74 & 2.02 & 5.05 & K42 & 42.51 & 47.33 & 0.01 & 0.04 & 0.05 \\
\hline K14 & 32.21 & 38.19 & 0.02 & 0.05 & 0.06 & K43 & 63.10 & 66.09 & 0.01 & 0.04 & 0.04 \\
\hline K15 & 84.70 & 169.57 & 0.35 & 1.89 & 3.78 & K44 & 64.27 & 147.31 & 0.56 & 2.30 & 5.28 \\
\hline K16 & 45.67 & 105.79 & 0.58 & 1.69 & 3.92 & K45 & 57.62 & 136.35 & 0.63 & 2.29 & 5.41 \\
\hline K17 & 80.71 & 180.19 & 0.52 & 2.65 & 5.92 & K46 & 44.34 & 105.95 & 0.65 & 1.81 & 4.34 \\
\hline K18 & 86.69 & 162.26 & 0.27 & 1.49 & 2.79 & K47 & 32.88 & 86.19 & 0.85 & 1.77 & 4.66 \\
\hline K19 & 46.16 & 49.65 & 0.01 & 0.04 & 0.04 & K48 & 33.88 & 36.70 & 0.01 & 0.03 & 0.03 \\
\hline K20 & 38.19 & 42.51 & 0.01 & 0.04 & 0.04 & K49 & 87.19 & 113.93 & 0.04 & 0.26 & 0.34 \\
\hline K21 & 76.39 & 81.71 & 0.01 & 0.06 & 0.06 & K50 & 63.44 & 132.53 & 0.41 & 1.65 & 3.46 \\
\hline K22 & 47.66 & 96.66 & 0.37 & 1.11 & 2.26 & K51 & 65.76 & 76.23 & 0.02 & 0.09 & 0.11 \\
\hline K23 & 64.43 & 117.41 & 0.24 & 0.99 & 1.81 & K52 & 61.28 & 67.26 & 0.01 & 0.06 & 0.06 \\
\hline K24 & 54.47 & 59.12 & 0.01 & 0.05 & 0.05 & K53 & 77.22 & 87.19 & 0.01 & 0.09 & 0.10 \\
\hline
\end{tabular}




\begin{tabular}{|l|c|c|c|c|c|c|c|c|c|c|c|}
\hline K25 & 65.60 & 72.57 & 0.01 & 0.07 & 0.07 & K54 & 85.86 & 92.17 & 0.01 & 0.07 & 0.08 \\
\hline K26 & 53.81 & 58.12 & 0.01 & 0.04 & 0.05 & K55 & 100.64 & 112.10 & 0.01 & 0.11 & 0.12 \\
\hline K27 & 76.23 & 128.87 & 0.17 & 0.85 & 1.44 & Average & 62.07 & 93.36 & 0.18 & 0.68 & 1.43 \\
\hline K28 & 85.03 & 102.80 & 0.03 & 0.16 & 0.19 & Max & 139.01 & 243.97 & 0.94 & 2.76 & 7.49 \\
\hline K29 & 90.68 & 134.35 & 0.09 & 0.54 & 0.80 & Min & 32.21 & 36.70 & 0.008 & 0.02 & 0.02 \\
\hline
\end{tabular}

Table 3:- Comparison between concentrations of $\operatorname{radon}(\mathrm{C})$ in the air of dwellings in the city of Karbala and some of the results of the concentrations of radon levels in the air of some countries of the world.

\begin{tabular}{|c|c|c|c|c|c|c|c|}
\hline No. & Country & $\mathrm{C} \mathrm{Bq} / \mathrm{m}^{3}$ & Ref. & No. & Country & $\mathrm{C} \mathrm{Bq} / \mathrm{m}^{3}$ & Ref. \\
\hline 1 & Iraq & 51.688 & {$[19]$} & 13 & USA & 46 & {$[31]$} \\
\hline 2 & Iraq & 63.767 & {$[20]$} & 14 & Romania & 112 & {$[32]$} \\
& & & & & & & \\
\hline 3 & Iraq & 116.78 & {$[21]$} & 15 & France & 68 & {$[33]$} \\
\hline 4 & Jordan & 144 & {$[22]$} & 16 & Spain & 86 & {$[34]$} \\
\hline 5 & Kosovo & 95.4 & {$[23]$} & 17 & Greece & 41 & {$[35]$} \\
\hline 6 & Iran & 94 & {$[24]$} & 18 & Turkey & 130 & {$[36]$} \\
\hline 7 & Ghana & 466.9 & {$[25]$} & 19 & Saudi Arabia & 18.4 & {$[37]$} \\
\hline 8 & Jordan & 111 & {$[26]$} & 20 & Egypt & 65.97 & {$[38]$} \\
\hline 9 & Libya & 29.7 & {$[27]$} & 21 & Yamen & 44 & {$[39]$} \\
\hline 10 & Palestine & 78.6 & {$[28]$} & 22 & Sudan & 92.38 & {$[40]$} \\
\hline 11 & India & 97.68 & {$[29]$} & 23 & Iraq & 70.358 & {$[41]$} \\
\hline 12 & Mali & $70-154$ & {$[30]$} & 24 & This study & 62.07 & - \\
\hline
\end{tabular}

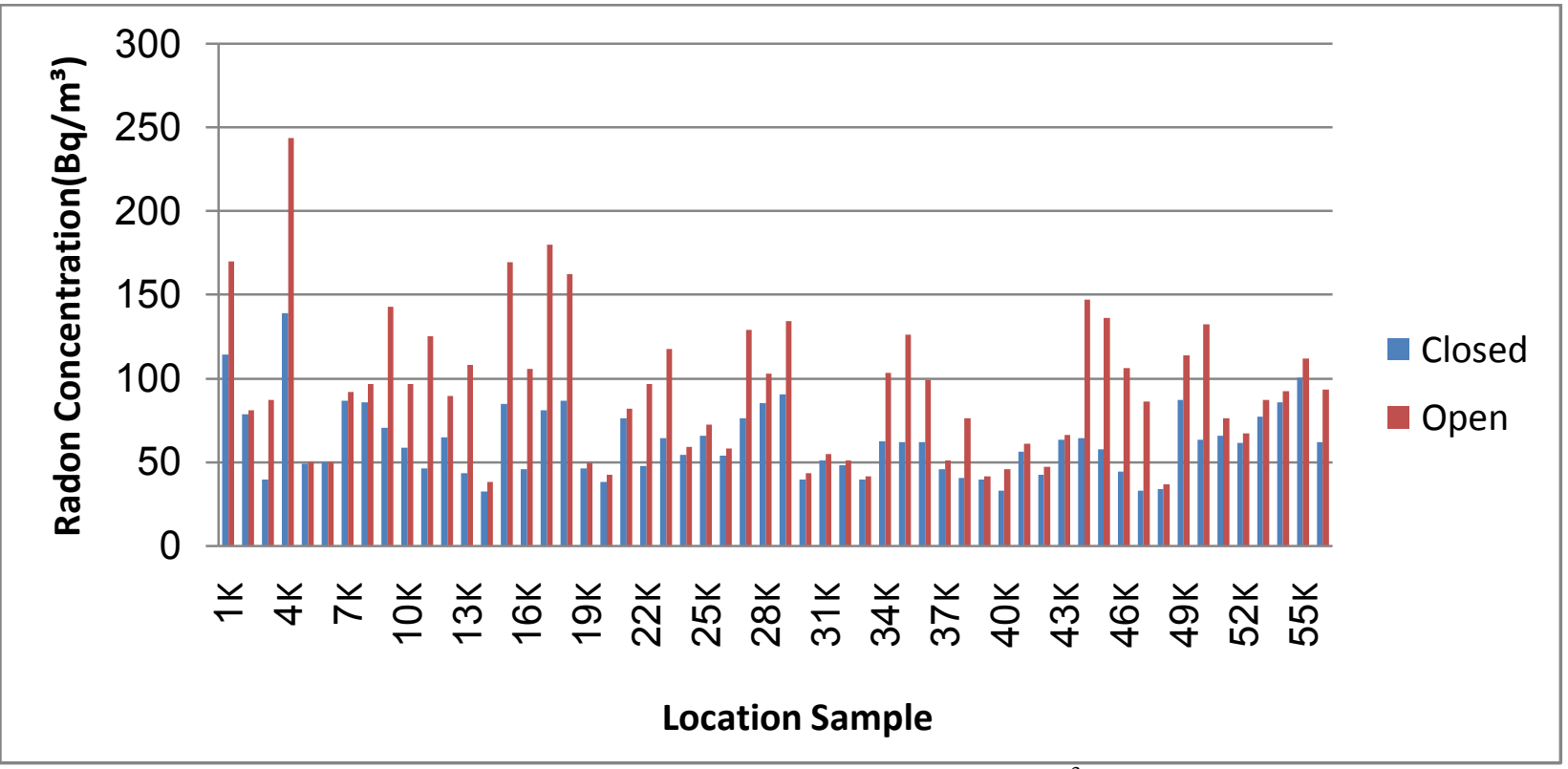

Figure 3:- A histogram illustrating the change in radon gas concentration $\left(\mathrm{Bq} / \mathrm{m}^{3}\right)$ in indoor dwelling samples for closed and open dosimeters in all regions studied. 


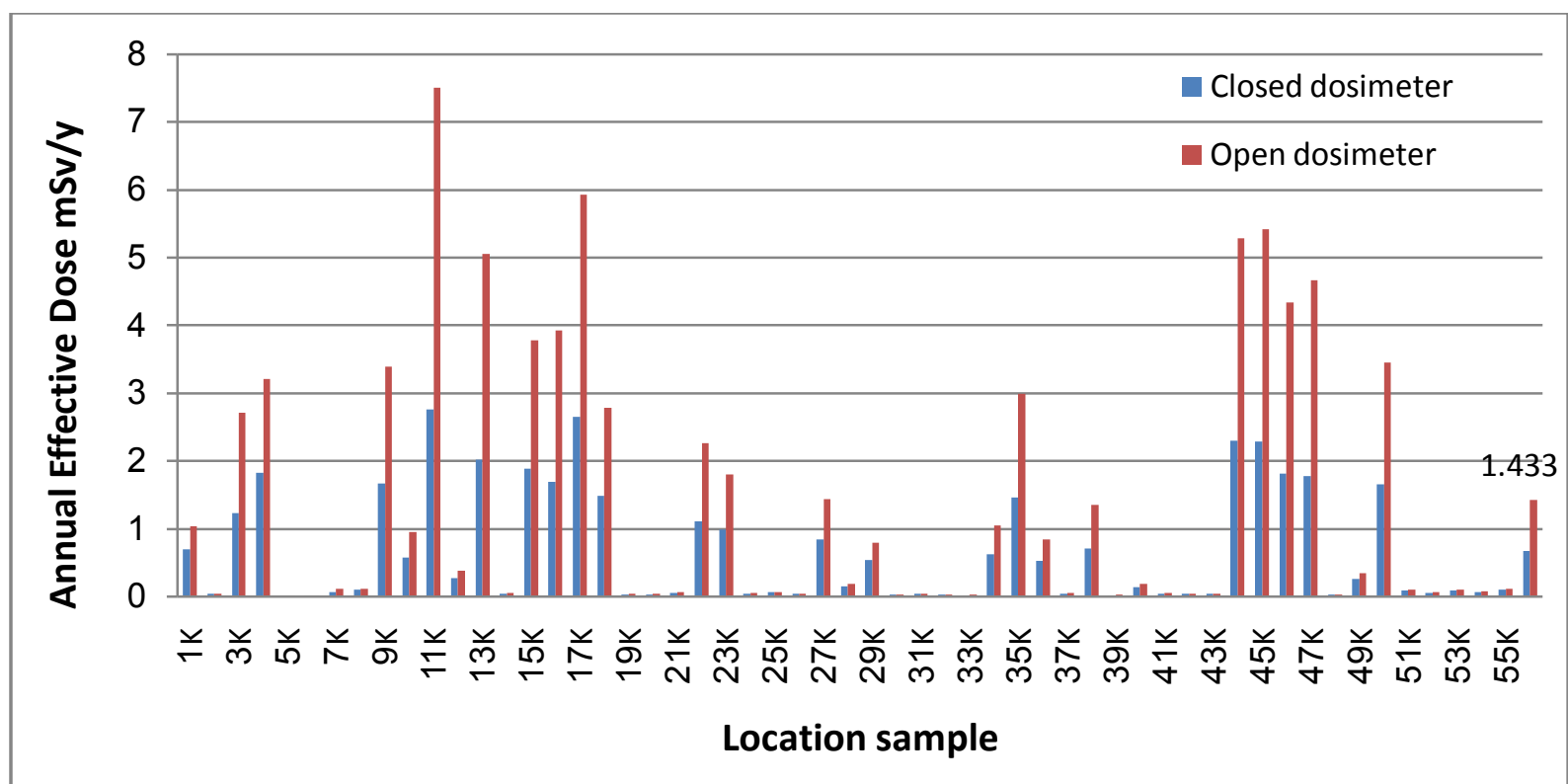

Figure 4:- A histogram illustrating the change in annual effective dose of radon gas concentration $(\mathrm{mSv} / \mathrm{y})$ in indoor dwelling samples for closed and open dosimeters in all regions studied.

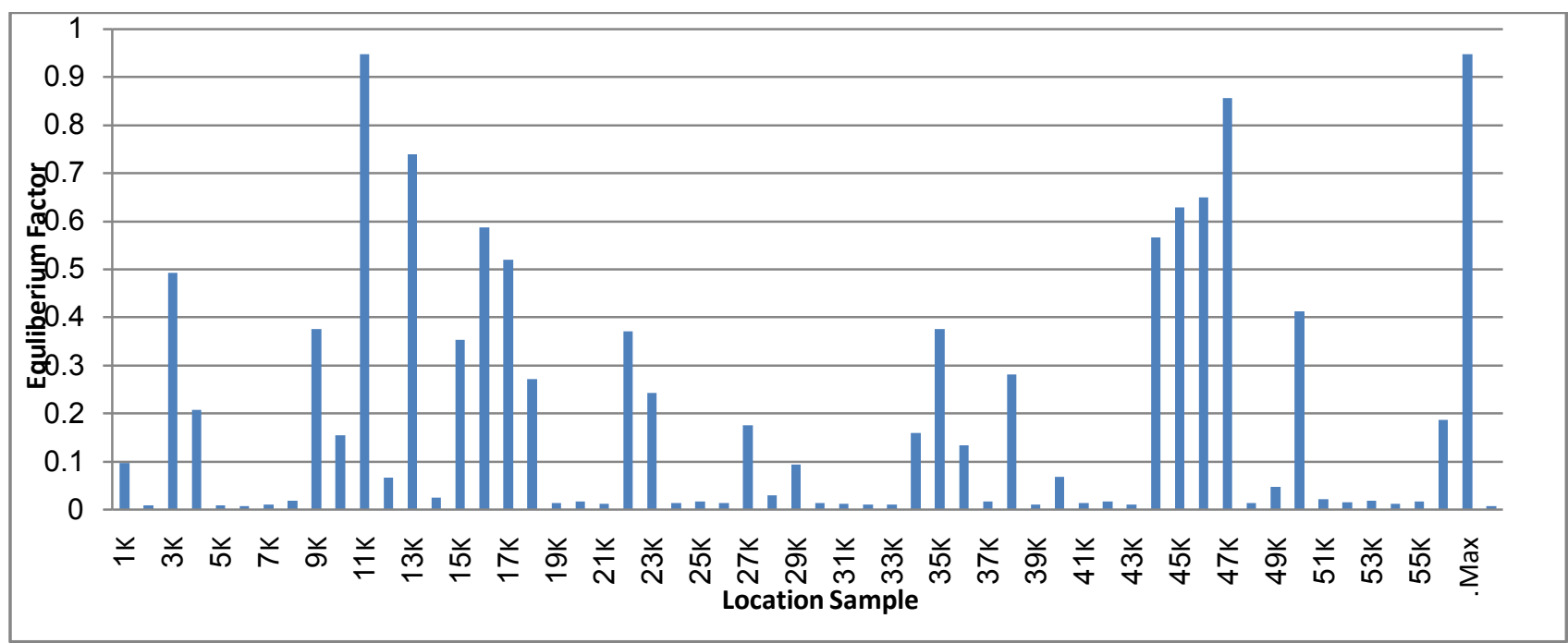

Figure5:- A histogram illustrating the change in equilibrium factor of radon gas concentration in indoor dwelling samples for closed and open dosimeters in all regions studied.

\section{Conclusions:-}

The results of the present work provide an additional database on indoor radon level in Karbala city in Kerbala governorate of Iraq. Were measured concentrations of radon gas in the air of 55 homes have varied results of measurements from house to house, because of the building houses the way and the behaviour of its inhabitants population, plus ways and methods of ventilation and the use of cooling and heating, as well as some of the population are smoking at home. These factors caused the difference in the concentrations of radon gas. However, the measurements that are made in the city of Karbala, was less than a lot of the measurements made in many countries of the world.. It is within the allowable limits and do not pose a threat to human health. You can conduct research and studies and continuous patrol of the various cities in Iraq to see radioactivity and to reduce the health effects on human life. 


\section{References:-}

1. R. G. Budnitz, "Radon-222 and its Daughters", Health Phys., 26 (1974), 145-163.

2. M. S. Baxter, "Environmental Radioactivity: A Perspective on industrial Contributions", International Atomic Energy Agency (IAEA) Bulletin, 35 (2) (1993), 33-38.

3. D. Sumner, T. Wheldon and W. Watson, Radiation Risks, Glasgow, UK: The Tarragon Press, 1991, 32-43.

4. F. I. Hassan, "Indoor Radon Concentration Measurements at Hebron University Campus", An-Najah University Journal for Research, 4 (10) (1996), 92-107.

5. B. G. Cartwright, E. K. Shirk, and P. B. Price," A Nuclear Recording Polymer of Unique Sensitivity and Resolution", Nucl. Inst. Methods., 153 (1987), 457-460.

6. G. C. Camplin, D. L. Henshaw, S. Lock, and Z. Simmons, "A National Survey of Background Alpha Particle Radioactivity", Phys. Educ., 23 (1988), 212-217.

7. J. B. Brenner, Radon Risk and Remedy. New York: Freeman, 1989.

8. MuayedSajet, "Spatial analysis of residential waste solid in the city of Karbala (a study in environment geography)",Master Thesis, College of education for Humanities Geography, University of Karbala,( 2015).

9. Fazal R., Jamil K., Zakaullah M. , Abu-Jarad F., MujahidS.A.,Experimental and Monte Carlo simulation studies of open cylindrical radon monitoring device using CR-39 detector. Journal of Environmental Radioactivity, 65, 243-254, (2003).

10. Rafat M., Amin M., Eissa F., "Radon level and radon effective dose rate determination using SSNTDs in scanner cave, Eastern desert of Egypt" Environ Monit Assess, Vol.143, 59-65, (2008).

11. Abdalsattar Kareem Hashim., (2003), A Study of Radon Concentration in the Soil and air of Some Villages in Irbid Governorate., " M.Sc. Thesis, Yarmouk University, Jordan.

12. Faj, Z. and Planinic, (1991). Dosimetry of radon and its daughters by tow SSNT detectors. Radiat. Prot. Dosim., $35,265-8$.

13. Mowlavi A.,M., Fornasier M.R., Binesh A. and de Denaro M. " Indoor radon measurement and effective dose assessment of 150 apartments in Mashhad, Iran" Environ Monit Assess, 184, 1085-1088, (2012) .

14. UNSCAER Appendix I: Epidemiological evaluation of radiation induced cancer; Appendix G: Biological effects of low radiation doses, (2000).

15. Abumurad, K. M., Al-Omari R. A., "Indoor radon levels in Irbid and health risks from internal doses. Radiation Measurements", 43, S389-S391, (2008).

16. ICRP, International Commission on Radiological Protection Statement on Radon. ICRP, Ref. 00/902/09, (2009).

17. ICRP, "Protection Against Rn-222 at Home and at Work" International Commission on Radiological Protection Publication 65. Ann. ICRP 23 (2). Pergamon Press; Oxford, (1993).

18. UNSCEAR. United Nations Scientific Committee on the Effects of Atomic Radiation: Sources and Effects of Ionizing Radiation, Vol.1.United Nations, New York, 2000.

19. Hazim Louis Mansour, Nada FathilTawfiq and Mahmood Salim Karim., Measurement of radon -222 concentrations in dwellings of Baghdad Governorate.,INDIAN JOURNAL OF APPLIED RESEARCH.,4 , 2 , 2014(1-4).

20. Abdalsattar Kareem Hashim, Hamza A. Mezher, Radon Concentrations and Annual Effective Dose inSome Dwellings of Aun Region in KerbalaGovernorate, Iraq., Journal of Kerbala University, Vol. 14 No.1 Scientific . 2016(103-111).

21. Nada F. Tawfiq, Noora O. Rasheed, Asmaa Ahmad Aziz, Measurement of Indoor Radon Concentration in Various Dwellings of Baghdad Iraq., International Journal of Physics, 2015, 3, 5, 202-207.

22. K.M. Abumurad, M.H. Al-Tamimi, Natural radioactivity due to radon in Soum region, Jordan., Radiation Measurements 39 (2005) $77-80$.

23. M. Bahtijari, J. Vaupotic, A. Gregoric, P. Stegnar and I. Kobal., EXPOSURE TO RADON IN DWELLINGS IN THE SHARRICOMMUNITY, KOSOVO., Radiation Protection Dosimetry (2008), 130, 2, 244-248.

24. K. Hadad, M.R. Hakimdavoud, M. Hashemi-Tilehnoee, Indoor radon survey in Shiraz-Iran using developed passive measurement method., Iran. J. Radiat. Res., 9(3): 175-182(2011).

25. I. Nsiah-Akoto, J.J. Fletcher, O.C. Oppon and A.B. Andam., Indoor Radon Levels and the Associated Effective Dose Rate Determination atDome in the Greater Accra Region of Ghana. Research Journal of Environmental and Earth Sciences 3(2): 124-130, 2011.

26. M. M. Ya'qouba, I. F. Al-Hamarneha and M. Al-Kofahib, Indoor Radon Concentrations and Effective Dose Estimation inDwellings of As-Salt Region in Jordan., Jordan Journal of Physics 2, 3, 189-196(2009). 
27. Rafat M. Amin., Evaluation of radon gas concentration in the drinking water and dwellings of south-west Libya, using CR-39 detectors ., INTERNATIONAL JOURNAL OF ENVIRONMENTAL SCIENCES 4,4, 484490(2013).

28. M. M.Abu-Samreh, K. M. Thabayneh, M.M. Elayan.,Assessment of indoor radon levels in some dwellings of BeitFajjar city, Palestine.,Hebron University Research Journal (A). 6, 47 - 60, 2012.

29. RohitMehra, and PankajBala., Effect of ventilation conditions on the annual effective dose due to indoor radon concentration., Advances in Applied Science Research, 4(1):212-215(2013).

30. I. TRAORÉ, A. NACHAB2, A. BÂ, A. NOURREDDINE, V. TOGO., Assessment of activity and effective doserate of 222Rn in several dwellingsin Bamako, Mali., Radioprotection ( 9:01 09) (1-8)2012.

31. Lucas, R.M., Grillo, R.B. and Kemp, S.S. (1992c). EPA (U.S. Environmental Protection Agency), National Residential Radon Survey. Vol. 1:national and regional estimates, Report prepared for the Office of Radiation Programs .

32. Szacsvai K., Cosma C. and Cucos A., Indoor radon exposure in Cluj-Napoca city Romania. Rom.Journ. Phys. 58, S273-S279 (2013).

33. Baysson H., Billon S., Laurier D., Rogal A. and Tirmarche M., Seasonal correction for estimationradon exposure in France dwellings. RadiatProtDosim 104(3), 245-252 (2003).

34. UNSCEAR, United Nation Scientific Committee on the Effects of Atomic Radiation. Sources andEffects of Ionizing Radiation, United Nations: New York (1993).

35. H. Papaefthymiou, A. Mavroudis and P. Kritidis, Indoor radon levels and influencing factors inhouses of Patras, Greece, Journal of Environmental Radioactivity 66, 247-260 (2003).

36. N. Celik, U. Cevik and B. Kucukomeroglu, Determination of indoor radon and soil radioactivity levels in Giresun, Turkey, Journal of Environmental Radioactivity 99, 1349-1354 (2008).

37. S. Ferdoas and Al-Saleh, Measurements of indoor gamma radiation and radon concentrations in dwellings of Riyadh City, Saudi Arabia, Applied Radiation and Isotopes 65: 843-848 (2007).

38. H. A. Abdel Ghany, Variability of radon levels in different rooms of Egyptian dwellings, Indoor and Built Environ 15 (2), 193 (2006).

39. A. H. Khayrat, M. I. Al-Jarallah, X. Fazal-ur-Rehman, and F. Abu-Jarad, Indoor radon survey in dwellings of some regions in Yemen, RadiatMeas 36, 449-451 (2003).

40. Abd-Elmoniem A. Elzain§1, Adam K. Sam2, Othman M. Mukhtar3, Mustafa A. Abbasher., A Survey of Indoor Radon - 222 levels in Kassala town., Gezira j. of eng.\& applied sci.3 (2) :72-100(2008)

41. Abbas, J. Al-saadi., Determination of Radon Concentration and the Annual Effective Dose in Karbala University Campus, Karbala, IraqKarbala J. Med. 6, 1(1591-1599)(2013). 